\title{
ANALISIS PENGARUH PEMBERIAN KREDIT TERHADAP LOAN TO DEPOSIT RATIO DAN DAMPAKNYA PADA PENDAPATAN (STUDI PADA PT BPR LENGAYANG PESISIR SELATAN)
}

\author{
Afriyeni, Romi Susanto \\ Akademi Keuangan dan Perbankan Padang \\ afriyeni@akbpstie.ac.id
}

\begin{abstract}
The objective of this research are to know: (1) the influence of credit to loan to deposit ratio in PT BPR Lengayang Pesisir Selatan; (2) the influence of credit and loan to deposit ratio (LDR) partially to interest income of bank in PT BPR Lengayang Pesisir Selatan; (3) the influence of credit canalization and loan to deposit ratio simultaneously to interest income of bank in PT BPR Lengayang Pesisir Selatan. Research method applied analytical descriptive method with case study approach. Analyzer applied is path analysis. Testing of hypothesis according to partially use test $t$ and simultan use test $F$ with level significances that used as big as 95\% $(\alpha=0,05)$. The result of research indicated that: (1) credit canalization influences unsignificant to loan to deposit ratio; (2) credit canalization partially influences significant to interest income of bank; (3) loan to deposit ratio partially influences unsignificant to interest income of bank; and (4) credit canalization and loan to deposit ratio simultaneous influences significant to interest income of bank.
\end{abstract}

Keyword: Credit, Loan to Deposit Ratio and Interest Income of Bank

\section{PENDAHULUAN}

Fenomena manusia sebagai makhluk sosial adalah suatu hal yang tidak dapat dipungkiri. Manusia umumnya sulit untuk melakukan suatu kegiatan tanpa bantuan dari orang lain baik itu secara langsung maupun tidak langsung, begitupun dalam kegiatan pemenuhan kebutuhannya terutama dalam memenuhi kebutuhan perekonomian. Kebutuhan perekonomian diantaranya adalah kebutuhan sandang, pangan, dan papan dimana kebutuhan-kebutuhan ini dapat dipenuhi melalui kegiatan industri, perdagangan, pelayanan jasa dan kegiatankegiatan ekonomi lainnya yang notabanenya akan menghasilkan penghasilan yang dapat digunakan untuk pemenuhan kebutuhan.

Kegiatan-kegiatan ekonomi di atas, tentunya pada tahapan awal pasti memerlukan modal, baik itu modal kerja atau modal skill. Modal skill dapat diperoleh melalui sarana pendidikan sedangkan modal kerja dapat diperoleh dari modal sendiri maupun pinjaman. Modal yang berasal dari pinjaman biasanya dapat diperoleh dari lembaga-lembaga keuangan atau lembaga non keuangan yang 
memiliki izin operasi untuk melakukan kegiatan dalam bidang keuangan. Salah satu lembaga keuangan yang dapat memberikan pinjaman adalah bank.

Bank menurut Ikatan Akuntan Indonesia (SAK, 2007 : 31.1) adalah "lembaga yang berperan sebagai perantara keuangan (financial intermediary) antara pihak yang memiliki dana dan pihak yang memerlukan dana, serta sebagai lembaga yang berfungsi memperlancar lalu lintas pembayaran". Sedangkan menurut Eeng Ahman (2004 : 107) mengatakan bahwa "pada dasarnya yang dimaksud dengan bank adalah lembaga keuangan yang menghimpun dana dari masyarakat yang kelebihan dana dan menyalurkannya kepada masyarakat yang kekurangan dana".

Dari kedua definisi tersebut dapat disimpulkan bahwa bank adalah lembaga keuangan yang kegiatan utamanya menghimpun dana dari masyarakat dan menyalurkannya kembali kepada masyarakat. Kegiatan penghimpunan dana dari masyarakat ini bisa dalam bentuk tabungan, deposito, giro, dan lain-lain. Sedangkan dalam kegiatan penyaluran dana kepada masyarakat bisa dalam bentuk investasi atau kredit.

Pemberian kredit merupakan salah satu kegiatan bank dalam usahanya sebagai lembaga yang dipercaya untuk berperan dalam mendorong pertumbuhan ekonomi rakyat. Dalam hal ini, bank memberikan bantuan modal kepada masyarakat untuk memenuhi kebutuhannya terutama kebutuhan modal kerja melalui sarana kredit.

Kredit menurut UU No. 7 tahun 20 menyatakan bahwa "kredit adalah peminjaman uang atau tagihan yang dapat dipersamakan dengan itu berdasarkan persetujuan atau kesepakatan pinjam-meminjam antara bank dan pihak lain yang mewajibkan pihak peminjam untuk melunasi utangnya setelah jangka waktu tertentu dengan jumlah bunga, imbalan, atau pembagian hasil keuntungan". Dengan adanya timbal balik atas pemberian kredit maka kredit merupakan salah satu sumber penghasilan bagi bank. Terutama bagi bank konvensional, pendapatan dari kegiatan kredit ini dapat berupa pendapatan bunga. Semakin besar jumlah kredit yang disalurkan maka akan semakin besar pula pendapatan bunga yang akan diperoleh oleh bank.

Adapun sumber dana yang digunakan untuk pemberian kredit dapat berasal dari dana bank itu sendiri dan atau dana pihak ketiga atau dana yang berhasil dihimpun dari masyarakat. Jumlah kredit yang diberikan dan jumlah dana yang digunakan bank untuk memberikan kredit merupakan indikator yang digunakan untuk menilai kesehatan bank.

Penilaian kesehatan bank ini dapat dilihat dari salah satu rasio likuiditas yaitu rasio untuk mengukur komposisi jumlah kredit yang diberikan dibandingkan dengan jumlah dana masyarakat dan modal sendiri yang digunakan (Kasmir, 2008:290). Rasio ini dikenal dengan sebutan Loan to Deposit Ratio atau dapat disingkat dengan LDR.

Dengan memperhatikan jumlah kredit yang diberikan sebagai salah satu indikator yang dapat mempengaruhi LDR, maka semakin banyak jumlah kredit yang diberikan semakin tinggi pula LDR, dan begitu sebaliknya. Hal ini dapat pula menunjukan bahwa pada saat jumlah kredit yang diberikan dan LDR tinggi maka laba yang diperoleh bank melalui pendapatan bunga pun akan tinggi. 
Peneliti mencoba melakukan penelitian pada salah satu lembaga keuangan yang ada di Pesisir Selatan yaitu PT BPR Lengayang Pesisir Selatan, dimana lembaga ini merupakan salah satu lembaga keuangan bank. Adapun kegiatan usahanya yaitu menerima dana dari masyarakat dan menyalurkannya dalam bentuk kredit. Penelitian ini ditekankan pada tiga hal yaitu pemberian kredit, loan to deposit ratio (LDR) dan pendapatan bunga bank.

Menurut Bank Indonesia dalam Laporan Pengawasan Perbankan 2008 disebutkan bahwa penyaluran kredit BPR Konvensional tumbuh lebih tinggi dari penghimpunan DPK . Kredit meningkat sebesar Rp 4,9 triliun (24,0\%), sementara DPK meningkat $\mathrm{Rp} 2,6$ triliun (14,0\%) sehingga loan to deposit ratio (LDR) meningkat menjadi $119,4 \%$. Pencapaian LDR tersebut tergolong tinggi, namun masih aman bagi kesehatan BPR karena penyaluran kredit tersebut tidak semata dibiayai dari DPK , tetapi juga menyertakan modal dan pinjaman. Fenomena yang terjadi pada BPR Konvensional dengan adanya pertumbuhan penyaluran kredit yang lebih tinggi dan posisi LDR yang masih dikatakan cukup aman dengan melihat faktor-faktor lainnya, dapat mencerminkan bahwa pendapatan bunga bank pun mengalami pertumbuhan yang searah. Pernyataan Bank Indonesia dalam laporannya tersebut tentunya mencakup PT BPR Lengayang Pesisir Selatan.

Berdasarkan uraian di atas penulis beranggapan bahwa penelitian mengenai pengaruh pemberian kredit terhadap salah satu ratio likuiditas dalam hal ini LDR sangatlah penting untuk menilai kesehatan bank dan membantu dalam kebijakan pemberian kredit. Selain itu, besar kecilnya jumlah kredit yang diberikan dan tinggi rendahnya nilai LDR dapat berdampak pada pendapatan bunga bank.

\section{TINJAUAN PUSTAKA}

Menurut Undang-undang No.10 Tahun1998 tentang perbankan pengertian kredit adalah penyediaan uang atau tagihan yang dapat dipersamakan dengan itu, berdasarkan persetujuan atau kesepakatan pinjam meminjam antara bank dengan pihak lain yang mewajibkan pihak peminjam untuk melunasi utangnya setelah jangka waktu tertentu dengan pemberian bunga.

Ikatan Akuntan Indonesia (SAK, 2007 : 31.11) menyatakan bahwa "kredit adalah peminjaman uang atau tagihan yang dapat dipersamakan dengan itu berdasarkan persetujuan atau kesepakatan pinjam-meminjam antara bank dan pihak lain yang mewajibkan pihak peminjam untuk melunasi utangnya setelah jangka waktu tertentu dengan jumlah bunga, imbalan, atau pembagian hasil keuntungan".

Dari kedua pengertian di atas, dapat disimpulkan bahwa kredit merupakan kegiatan atau usaha bank dalam rangka menyalurkan dana kepada pihak yang membutuhkan dana dengan dimana peminjam memiliki kewajiban untuk melunasi utangnya setelah jangka waktu tertentu dengan bunga, imbalan atau pembagian hasil.

Loan to Deposit Ratio (LDR)

Menurut Dendawijaya (2009 : 116), pengertian loan to deposit ratio (LDR) adalah "rasio antara jumlah kredit yang diberikan bank dengan dana yang diterima oleh bank. Sedangkan Kasmir (2008 : 290) menyatakan bahwa "loan to deposit ratio merupakan rasio untuk mengukur komposisi jumlah kredit yang diberikan 
dibandingkan dengan jumlah dana masyarakat dan modal sendiri yang digunakan., besarnya loan to deposit ratio (LDR) menurut peraturan pemerintah maksimum adalah $110 \%$. Semakin tinggi rasio tersebut memberikan indikasi semakin rendahnya kemampuan likuiditas bank yang bersangkutan. Hal ini disebabkan karena jumlah dana yang diperlukan untuk membiayai kredit menjadi semakin besar. Rasio ini juga merupakan indikator kerawanan dan kemampuan dari suatu bank.

Pendapatan Bunga Bank

Pendapatan menurut Ikatan Akuntan Indonesia (SAK, 2007 : 23.06) adalah "arus masuk bruto dari manfaat ekonomi yang timbul dari aktivitas normal perusahaan selama suatu periode bila arus kas masuk tersebut mengakibatkan kenaikan ekuitas, yang tidak berasal dari kontribusi penanaman modal". Demikian halnya dengan yang disebutkan dalam tujuan SAK per September 2007 no. 23 bahwa "pendapatan adalah penghasilan yang timbul dari aktivitas perusahaan yang biasa dan dikenal dengan sebutan yang berbeda seperti penjualan, penghasilan jasa (fee), bunga, deviden, royalti, dan sewa”. Adapun dalam perusahaan perbankan salah satu sumber pendapatan adalah pendapatan bunga.

Adapun, bunga dalam posisinya sebagai pendapatan menurut Malayu Hasibuan (2005 : 18) adalah "balas jasa atas pinjaman uang atau barang yang dibayar debitur kepada kreditur".

Kerangka Pemikiran

Bank merupakan salah satu lembaga keuangan yang memiliki peranan sangat penting bagi masyarakat. Hal ini dikarenakan masyarakat yang memerlukan modal untuk memenuhi kebutuhan-kebutuhannya, dimana bank mampu menyediakan modal untuk membantu pemenuhan kebutuhan tersebut. Selain itu, bank dapat diartikan lembaga yang berperan sebagai perantara keuangan (financial intermediary) antara pihak yang memiliki dana dan pihak yang memerlukan dana, serta sebagai lembaga yang berfungsi memperlancar lalu lintas pembayaran (SAK, $2007: 31.1$ ).

Sebagai lembaga yang memiliki peran penting tersebut, maka hal utama yang akan menjadi persoalan bagi sebuah bank adalah masalah dana. Tanpa adanya dana, bank tidak dapat menjalankan aktivitasnya sebagai perantara keuangan (financial intermediary). Selain itu juga, pertumbuhan suatu bank dapat dilihat dari jumlah dana yang dapat dihimpun oleh bank tersebut.

Dana-dana yang dimiliki bank dapat diperoleh dari 3 (tiga) sumber yaitu dari dana pihak kesatu (dana dari modal bank itu sendiri), dana pihak kedua (dana pinjaman dari pihak luar), dan dana pihak ketiga (dana dari masyarakat) (Lukman Dendawijaya, 2009 : 47). Dengan adanya dana-dana tersebut, kegiatan penyaluran dana pun akan berjalan dengan lancar. Kegiatan penyaluran dana dapat dilakukan melalui sarana kredit yang disediakan oleh bank.

Kredit menurut Ikatan Akuntan Indonesia (SAK, 2007:31.11) adalah peminjaman uang atau tagihan yang dapat dipersamakan dengan itu berdasarkan persetujuan atau kesepakatan pinjam-meminjam antara bank dan pihak lain yang mewajibkan pihak peminjam untuk melunasi utangnya setelah jangka waktu tertentu dengan jumlah bunga, imbalan, atau pembagian hasil keuntungan. 
Jumlah kredit yang diberikan oleh suatu bank dapat menunjukkan kemampuan bank tersebut dalam peranannya sebagai perantara keuangan. Selain itu, jumlah kredit yang diberikan merupakan salah satu indikator dalam penilaian kesehatan bank. Penilaian ini dapat dilihat melalui salah satu rasio likuiditas bank yaitu loan to deposit ratio (LDR).

LDR merupakan rasio untuk mengukur komposisi jumlah kredit yang diberikan dibandingkan dengan jumlah dana masyarakat dan modal sendiri yang digunakan (Kasmir, 2008 : 290). Dari pengertian tersebut, selain jumlah kredit yang diberikan terdapat dana masyarakat dan modal sendiri yang digunakan untuk kredit yang menjadi indikator dalam pembentukan LDR. Dana masyarakat ini bisa berupa tabungan atau deposito sedangkan modal sendiri bisa berupa modal, cadangan, atau laba ditahan. Oleh karena itu, besar kecilnya jumlah kredit yang diberikan oleh suatu bank akan mempengaruhi tinggi rendahnya nilai LDR yang dicapai oleh bank yang bersangkutan. Adapun, batas maksimal nilai LDR sesuai peraturan pemerintah adalah $110 \%$.

Tujuan didirikannya suatu bank salah satunya adalah untuk memperoleh keuntungan atau laba. Laba yang dapat diperolah oleh bank konvensional salah satunya berupa pendapatan bunga. Pendapatan bunga merupakan salah satu pos dalam pendapatan operasional yang berasal baik dari pinjaman yang diberikan maupun dari penanaman-penanaman yang dilakukan oleh bank, seperti giro, simpanan berjangka, obligasi, dan surat pengakuan utang lainnya.

Bunga dalam penelitian ini merupakan balas jasa atas pinjaman uang atau barang yang dibayar oleh debitur kepada kreditur (Hasibuan, 2005 : 18). Melalui kegiatan pemberian kredit bank akan memperoleh timbal balik berupa pendapatan bunga. Sehingga, dengan adanya jumlah kredit yang diberikan kepada masyarakat kegiatan pemberian kredit ini akan mempengaruhi prndaspatan bunga yang diperoleh bank.

Adapun hubungan antara LDR dengan pendapatan bunga dapat terjadi karena dalam perhitungan LDR terdapat indikator pemberian kredit yaitu jumlah kredit yang diberikan dimana dalam kegiatan pemberian kredit bank akan memperoleh timbal balik berupa pendapatan bunga. Oleh karena hal tersebut, LDR dapat mempengaruhi pendapatan bunga suatu bank.

Dari uraian di atas dapat disimpulkan bahwa, bank sebagai lembaga keuangan yang salah satu kegiatannya adalah melakukan pemberian kredit, dimana jumlah kredit yang diberikan merupakan salah satu indikator yang dapat berpengaruh dalam penilaian kesehatan bank. Penilaian kesehatan ini dilakukan dengan menghitung LDR. Adanya kegiatan ini juga akan berpengaruh pada pendapatan bunga yang diperoleh oleh bank. Hal ini dikarenakan dalam pemberian kredit akan ditetapkan sejumlah bunga yang akan menjadi pendapatan atau keuntungan bagi bank. Apabila dilihat secara keseluruhan, besar kecilnya pemberian kredit akan berpengaruh terhadap nilai LDR karena salah satu indikator dalam perhitungannya adalah jumlah kredit yang diberikan. Melalui pendapatan bunga yang dihasilkan dari kegiatan pemberian kredit ini, maka setiap perubahan yang terjadi pada jumlah kredit yang diberikan dan nilai LDR yang dicapai akan berdampak pula pada perubahan besar kecilnya pendapatan bunga yang diperoleh bank. 
Hipotesis :

1. Pemberian Kredit berpengaruh terhadap Loan to Deposit Ratio (LDR) pada PT. Bank Perkreditan Rakyat Lengayang Pesisir Selatan.

2. Pemberian Kredit dan Loan to Deposit Ratio (LDR) secara parsial berpengaruh terhadap Pendapatan Bunga Bank pada PT. Bank Perkreditan Rakyat Lengayang Pesisir Selatan.

3. Pemberian Kredit dan Loan to Deposit Ratio (LDR) secara simultan berpengaruh terhadap Pendapatan Bunga Bank pada PT. Bank Perkreditan Rakyat Lengayang Pesisir Selatan.

\section{METODE PENELITIAN}

Penelitian ini akan menggunakan metode deskriptif analisis dengan pendekatan studi kasus. Penelitian deskriptif menurut Nazir (2003 : 63) adalah suatu metode yang meneliti status kelompok manusia, objek, suatu set kondisi, suatu sistem pemikiran, ataupun suatu kelas peristiwa pada masa sekarang dengan tujuan deskripsi, gambaran atau lukisan secara sistematis, faktual dan akurat mengenai fakta-fakta, sifat serta hubungan antar fenomena yang diselidiki. Adapun metode studi kasus menurut Nazir (2003 : 66) adalah penelitian tentang status subjek penelitian yang berkenaan dengan suatu fase spesifik atau khas dari keseluruhan personalitas.

Operasionalisasi Variabel

Dalam penelitian ini terdiri dari tiga variabel yang terdiri dari dua variabel independen dan satu variabel dependen, yaitu sebagai berikut :

1. Variabel independen $(\mathrm{X})$

Dalam penelitian ini terdapat dua variabel independen yaitu pemberian kredit sebagai $\mathrm{X}_{1}$ dan loan to deposit ratio (LDR) sebagai $\mathrm{X}_{2}$.

2. Variabel dependen (Y). Dalam penelitian ini yaitu pendapatan bunga bank. 
Tabel 1.

Operasionalisasi Variabel

\begin{tabular}{|c|c|c|c|c|}
\hline variabel & Konsep variabel & Indikator & $\begin{array}{c}\text { Satua } \\
\mathrm{n}\end{array}$ & Skala \\
\hline $\begin{array}{l}\text { Pemberi } \\
\text { an } \\
\text { Kredit } \\
\left(\mathrm{X}_{1}\right)\end{array}$ & $\begin{array}{l}\text { kredit adalah peminjaman uang atau tagihan yang } \\
\text { dapat dipersamakan dengan itu berdasarkan } \\
\text { persetujuan atau kesepakatan pinjam-meminjam } \\
\text { antara bank dan pihak lain yang mewajibkan } \\
\text { pihak peminjam untuk melunasi utangnya setelah } \\
\text { jangka waktu tertentu dengan jumlah bunga, } \\
\text { imbalan, atau pembagian hasil keuntungan. } \\
(\mathrm{SAK}, 2007: 31.11)\end{array}$ & $\begin{array}{c}\text { Jumlah kredit } \\
\text { yang diberikan }\end{array}$ & $\begin{array}{c}\text { Rupia } \\
\mathrm{h}\end{array}$ & Rasio \\
\hline $\begin{array}{l}\text { Loan To } \\
\text { Deposit } \\
\text { Ratio } \\
(\text { LDR) } \\
\left(\mathrm{X}_{2}\right)\end{array}$ & $\begin{array}{l}\text { LDR merupakan rasio untuk } \\
\text { komposisi jumlah kredit yang } \\
\text { dibandingkan dengan jumlah dana masyarakat } \\
\text { dan modal sendiri yang digunakan. (Kasmir, } \\
2008: 290 \text { ) }\end{array}$ & $\begin{array}{l}\text {-jumlah kredit } \\
\text { yang diberikan } \\
\text { dana } \\
\text { masyarakat } \\
\text { (tabungan dan } \\
\text { deposito) } \\
\text {-modal sendiri } \\
\text { yang digunakan } \\
\text { (modal, } \\
\text { cadangan, laba) }\end{array}$ & $\begin{array}{l}\text { Perse } \\
\text { ntase }\end{array}$ & Rasio \\
\hline $\begin{array}{l}\text { Pendapat } \\
\text { an } \\
\text { Bunga } \\
\text { Bank } \\
\text { (Y) }\end{array}$ & $\begin{array}{l}\text { Bunga merupakan balas jasa atas pinjaman uang } \\
\text { atau barang yang dibayar oleh debitur kepada } \\
\text { kreditur (Hasibuan, } 2005: 18 \text { ) }\end{array}$ & $\begin{array}{l}\text { Besarnya } \\
\text { pendapatan } \\
\text { bunga bank }\end{array}$ & $\begin{array}{c}\text { Rupia } \\
\mathrm{h}\end{array}$ & Rasio \\
\hline
\end{tabular}

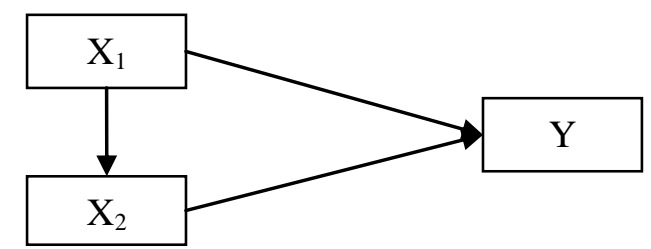

Gambar 2. Paradigma Penelitian

Teknik analisis data yang digunakan adalah analisis jalur (path analysis). Penggunaan teknik ini bertujuan untuk mengetahui pengaruh seperangkat variabel $\mathrm{X}$ (independent variable) dan untuk mengetahui pengaruh antara variabel $\mathrm{X}$. dalam analisis jalur ini dapat dilihat pengaruh dari setiap variabel secara bersamasama. Selain itu, tujuan dilakukannya analisis jalur ini adalah untuk menerangkan pengaruh langsung dan tidak langsung dari beberapa variabel penyebab terhadap variabel lainnya sebagai variabel terikat. Selain itu untuk mengetahui nilai LDR digunakan rumus sesuai definisi yang dikemukakan Kasmir (2008 : 290). Berikut ini adalah gambar diagram jalur sesuai dengan uraian di atas: 


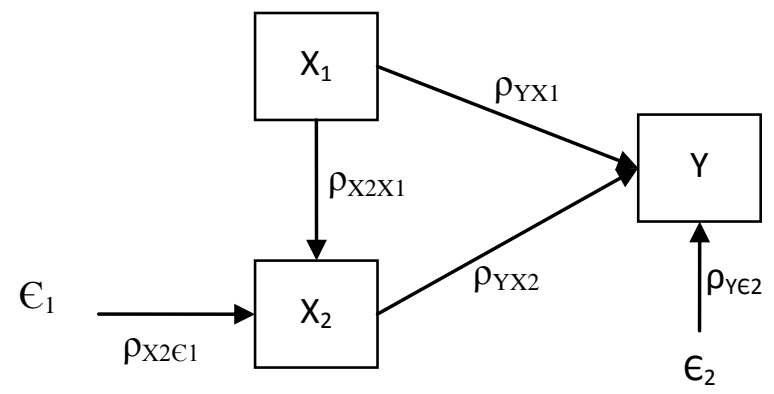

(Sitepu, 1994)

Dimana :

Gambar 3. Struktur lengkap Path Analysis

$\mathrm{X}_{1} \quad=$ Pemberian kredit

$\mathrm{X}_{2} \quad=$ Loan to deposit ratio $(\mathrm{LDR})$

$\mathrm{Y} \quad=$ Pendapatan bunga bank

$\mathrm{C} \quad=$ Faktor lain yang tidak diteliti

$\rho_{\mathrm{X} 2 \mathrm{X} 1}=$ Koefisian jalur antara variabel $\mathrm{X}_{1}$ terhadap variabel $\mathrm{X}_{2}$

$\rho_{\mathrm{YX} 1}=$ Koefisien jalur antara variabel $\mathrm{X}_{1}$ terhadap variabel $\mathrm{Y}$

$\rho_{\mathrm{YX} 2}=$ Koefisien jalur antara variabel $\mathrm{X}_{2}$ terhadap variabel $\mathrm{Y}$

$\rho_{\mathrm{X} 2 \epsilon 1}=$ Koefisien jalur antara variabel $\mathrm{X}_{2}$ terhadap variabel $\epsilon_{1}$

$\rho_{\mathrm{Y \epsilon} 2}=$ Koefisien jalur antara variabel $\mathrm{Y}$ terhadap variabel $\epsilon_{2}$

Dari struktur Path Analysis di atas, dapat dibagi sub-sub struktur yaitu sebagai berikut:

a. Sub struktur 1

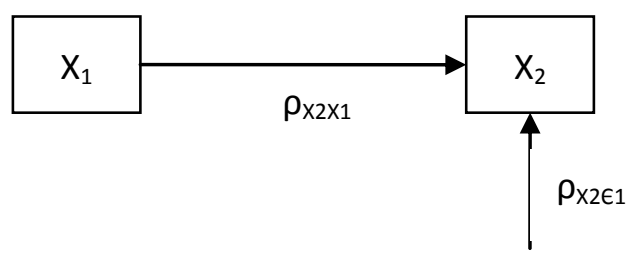

$\epsilon_{1}$

Gambar 4. Sub struktur 1

Sub struktur ini memperlihatkan hanya sebuah variabel penyebab dan variabel akibat. Dipandang dari sudut regresi, struktur ini tidak lain dari struktur linier sederhana. Dalam keadaan seperti ini, maka koefisien jalur tidak lain dari koefisien korelasi. 
b. Sub struktur 2

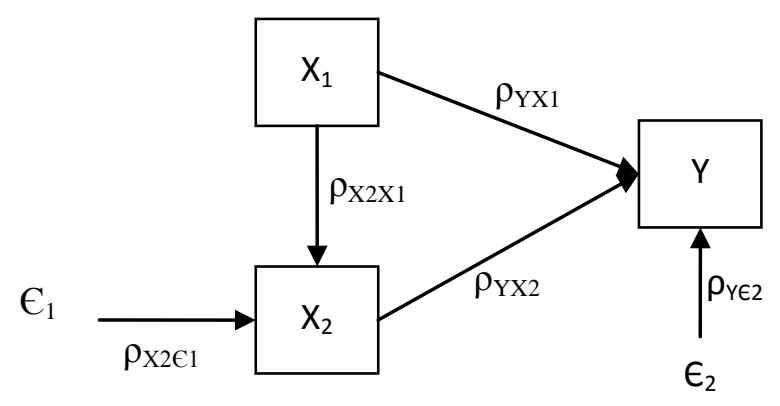

(Sitepu, 1994)

Gambar 5. Sub strukur 2

Sub struktur ini menjelaskan pengaruh antara pemberian kredit $\left(\mathrm{X}_{1}\right)$ dan loan to deposite ratio (LDR) $\left(\mathrm{X}_{2}\right)$ secara simultan terhadap pendapatan bunga bank $(\mathrm{Y})$. Berikut ini adalah langkah-langkah analisis data yang dapat digunakan berdasarkan struktur Path Analysis di atas :

1. Pengujian Koefisien Korelasi

Rumus yang digunakan untuk mengetahui koefisien korelasi adalah :

$$
\rho \mathrm{XiXj}=\frac{n \sum_{h=1}^{n} X i h . X j h-\left(\sum_{h=1}^{n} X i h\right)\left(\sum_{h=1}^{n} X j h\right)}{\sqrt{\left\{\left(n \sum_{h=1}^{n} X^{2} i h-\left(\sum_{h=1}^{n} X i h\right)^{2}\right\}\left\{n \sum_{h=1}^{n} X^{2} j h-\left(n \sum_{h=1}^{n} X j h\right)^{2}\right\}\right.}}
$$

Dengan $\mathrm{i} \neq j=1,2, \ldots, \mathrm{k}$

(Sitepu, 1994)

Tabel 2. Tingkat Keeratan Hubungan

\begin{tabular}{c|c}
\hline Interval Koefisien & Tingkat Hubungan \\
\hline $0,00-1,99$ & Sangat rendah \\
$0,20-0,399$ & Rendah \\
$0,40-0,599$ & Sedang \\
$0,60-0,799$ & Kuat \\
$0,80-1,00$ & Sangat kuat \\
\hline
\end{tabular}

(Sugiyono, $2008:$ 184)

2. Pengujian Simultan

Pengujian secara simultan menggunakan rumus sebagai berikut:

$$
\rho Y X i=\mathrm{bYXi} \sqrt{\frac{\sum_{\mathrm{h}=1}^{\mathrm{n}} \mathrm{Xi} \mathrm{h}{ }^{2}}{\sum^{n} \mathrm{Yh}^{2}}} \quad, i=1,2,3 \ldots \ldots \mathrm{k}
$$

Keterangan:

$\rho Y X i=$ Koefisien jalur dari variabel $\mathrm{X}_{1}$ terhadap variabel $\mathrm{Y}$

$\mathrm{bYXi}=$ Koefisien regresi variabel $\mathrm{X}_{1}$ terhadap variabel $\mathrm{Y}$

$\mathrm{i} \quad=1,2,3 \ldots \ldots ., \mathrm{k}$ 
3. Pengujian Faktor Residu/ Sisa

$$
\begin{aligned}
& \rho Y i \varepsilon=\sqrt{1-R^{2} Y_{i X} X_{2} \ldots X_{k}} \\
& \text { Dimana } \mathrm{R}^{2} \mathrm{YX}_{1} \mathrm{X}_{2} \ldots \ldots . . \mathrm{X}_{\mathrm{k}}=\sum_{i=1}^{k} \rho Y_{i} X_{i} r Y X i
\end{aligned}
$$

4. Pengujian Hipotesis Operasional

Menguji keberartian (signifikan) dari hubungan variabel bebas Xi dengan variabel $\mathrm{Xj}$

Ho: $\mathrm{r}_{X_{2} X_{1}}=0$

$\mathrm{Ha}: \mathrm{r}_{X_{2} X_{1}} \neq 0$

Dengan kriteria penolakan Ho jika $\mathrm{t}_{\text {hitung }}>\mathrm{t}_{\text {tabel }}$

a. Pengujian secara simultan

Ho : $\rho y x_{1}=\rho y x_{2}=0$

Ha : $\rho y x_{1}=\rho y x_{2} \neq 0$

Dengan kriteria penolakan Ho jika $\mathrm{F}$ hitung $>\mathrm{F}_{\text {tabel }}$

Uji signifikansi menggunakan rumus:

$$
\mathrm{F}=\frac{(n-k-1) R_{Y X_{1} X_{2} \ldots X_{k}}^{2}}{k\left(1-R_{Y X_{1} X_{2}}^{2}\right)}
$$

Statistik uji ini mengikuti distribusi $\mathrm{F}$ dengan derajat bebas $\mathrm{V}_{1}=\mathrm{k}$ dan $\mathrm{V}_{2}=$ n-k-1

b. Pengujian secara parsial

Hipotesis operasional:

Ho $: \rho_{Y X i}=0$

Ha $: \rho_{Y X i} \neq 0$

Uji statistik menggunakan rumus :

$$
\mathrm{t}_{\mathrm{i}}=\frac{\rho_{\mathrm{YX}_{1}}}{\sqrt{\frac{\left(1-\mathrm{R}_{\mathrm{YX}_{1} \ldots X_{k}}\right)}{(\mathrm{n}-\mathrm{k}-1)\left(1-\mathrm{R}_{\mathrm{X}_{\mathrm{i}} X_{1} \ldots\left(X_{i}\right) \ldots X_{k}}\right)}}} ; \mathrm{i}=1,2, \ldots,
$$

Statistik uji di atas mengikuti distribusi t dengan derajat bebas n-k-1

Untuk mencari besar pengaruh baik langsung maupun tidak langsung antara variabel $\mathrm{X}_{1}$ dan $\mathrm{X}_{2}$ terhadap $\mathrm{Y}$ adalah sebagai berikut :

Variabel $\mathrm{X}_{1}$

- Pengaruh langsung $\mathrm{Y} \leftarrow \mathrm{X}_{1} \rightarrow \mathrm{Y}: \rho \mathrm{yx}_{1} \cdot \rho \mathrm{yx}_{1}$

- Pengaruh tidak langsung $\mathrm{Y} \leftarrow \mathrm{X}_{1} \Omega \mathrm{X}_{2} \rightarrow \mathrm{Y}$ :

$$
\begin{aligned}
& \rho \mathrm{yx}_{1 .} \rho_{\mathrm{X} 2 \mathrm{X} 1 .} \rho_{\mathrm{X}} \\
& \text { Pengaruh } \mathrm{X}_{1} \rightarrow \mathrm{Y}
\end{aligned}
$$

$$
=\mathrm{A}
$$$$
=\underline{\mathrm{B}+}
$$$$
=\mathrm{C}
$$

Variabel $\mathrm{X}_{2}$

- Pengaruh Langsung $\mathrm{Y} \leftarrow \mathrm{X}_{2} \rightarrow \mathrm{Y}: \rho \mathrm{yx}_{2}$. $\rho \mathrm{yx}_{2}$

$$
=\mathbf{D}
$$

- Pengaruh Total $X_{1}$ dan $X_{2}$ terhadap $Y$ secara

$$
\text { Simultan }(\mathrm{C}+\mathrm{D})
$$$$
=\mathbf{E}
$$

Adapun rumus yang digunakan dalam mencari nilai loan to deposit ratio (LDR), adalah sebagai berikut: 


\section{Loan to Deposit Ratio $=\frac{\text { Total Loans }}{\text { Total Deposit }+ \text { Equity }} X 100 \%$}

\section{Uji Hipotesis}

(Kasmir, $2008: 290$ )

Uji hipotesis akan dimulai dengan penetapan hipotesis operasional, penetapan tingkat signifikan, uji signifikan, kriteria dan penarikan kesimpulan.

1. Penetapan hipotesis operasional

Ho $: \rho=0$ Pemberian kredit tidak berpengaruh terhadap loan to deposit ratio (LDR)

Ha $: \rho \neq 0$ Pemberian kredit berpengaruh terhadap loan to deposit ratio Ho : $\rho=0 \quad$ (LDR)

Ha $: \rho \neq 0 \quad$ pendapatan bunga bank

Pemberian kredit secara parsial berpengaruh terhadap pendapatan

Ho $: \rho=0 \quad$ bunga bank

Loan to deposit ratio (LDR) secara parsial tidak berpengaruh

$\mathrm{Ha}: \rho \neq 0 \quad$ terhadap pendapatan bunga bank

Loan to deposit ratio (LDR) secara parsial berpengaruh terhadap

Ho $: \rho=0$ pendapatan bunga bank

Pemberian kredit dan loan to deposit ratio (LDR) secara simultan

Ha $: \rho \neq 0 \quad$ tidak berpengaruh terhadap pendapatan bunga bank

Pemberian kredit dan loan to deposit ratio (LDR) secara simultan berpengaruh terhadap pendapatan bunga bank

2. Penetapan tingkat signifikan

Tingkat signifikan yang digunakan adalah $95 \%(\alpha=0,05)$ yang merupakan tingkat signifikansi yang sering digunakan dalam ilmu sosial yang menunjukkan ketiga variabel mempunyai korelasi cukup nyata.

3. Uji signifikan

a. Secara simultan menggunakan uji F.

b. Secara parsial menggunakan uji t.

4. Kaidah keputusan

Secara parsial

Tolak Ho jika $t_{\text {hitung }}>\mathrm{t}_{1 / 2} \alpha$ atau $-\mathrm{t}_{1 / 2} \alpha>\mathrm{t}_{\text {hitung }}$

Terima Ho jika $-\mathrm{t}_{1 / 2} \alpha \leq \mathrm{t}_{\text {hitung }} \leq \mathrm{t}_{1 / 2} \alpha$

Secara simultan

Tolak Ho jika $\mathrm{F}_{\text {hitung }}>\mathrm{F}_{\text {tabel }}$ dan terima Ho jika $\mathrm{F}_{\text {hitung }} \leq \mathrm{F}_{\text {tabel }}$

5. Penarikan kesimpulan

Berdasarkan hasil penelitian dan pengujian seperti tahapan di atas maka akan dilakukan analisis secara kuantitatif. Dari hasil tesebut akan ditarik kesimpulan apakah hipotesis yang ditetapkan dapat diterima atau ditolak. 


\section{PEMBAHASAN}

Kondisi jumlah kredit yang diberikan pada periode tersebut relatif naik setiap triwulannya. Walaupun terjadi penurunan pada beberapa triwulan namun penurunan tersebut tidak terlalu besar. Kondisi ini diduga karena permintaan terhadap kredit yang berfluktuasi.

Loan to deposit ratio (LDR) pada periode tersebut pada umumnya berada di bawah batas aman yang disepakati sebagian praktisi perbankan, hal ini dikarenakan dalam perbitungan LDR tidak hanya dana masyarakat saja yang digunakan sebagai pembanding akan tetapi juga modal.

Kondisi pendapatan bunga pada periode tersebut menunjukan terjadinya kenaikan dan penurunan yang tidak stabil dan cukup besar. Hal ini diduga karena terjadinya faktor-faktor seperti terjadinya kredit bermasalah atau persaingan.

Adapun variabel-variabel dalam penelitian ini adalah pemberian kredit sebagai variabel $\mathrm{X}_{1}$ dengan indikator yang digunakan adalah jumlah kredit yang diberikan; loan to deposit ratio (LDR) sebagai variabel $\mathrm{X}_{2}$ dengan indikator yang digunakan adalah jumlah kredit yang diberikan, dana masyarakat, dan modal sendiri yang digunakan; serta pendapatan bunga bank sebagai variabel $\mathrm{Y}$ dengan indikator yang digunakan adalah besarnya pendapatan bunga bank. Penelitian ini dilakukan dengan menganalisis laporan keuangan, dimana hasil dari penelitian ini merupakan hasil dari perhitungan statistik dan pengujian atas hipotesis dengan menggunakan analisis jalur. Perhitungan dilakukan dengan bantuan software program SPSS Versi 16.0 dengan tingkat signifikansi yang digunakan adalah $95 \%$ $(\alpha=0,05)$.

a. Pengaruh Pemberian Kredit terhadap Loan to Deposit Ratio (LDR) pada PT

Bank Perkreditan Rakyat Lengayang Pesisir Selatan

Hasil proses pengolahan data menunjukkan bahwa :

$$
\begin{array}{ll}
\rho_{\mathrm{x} 1 \times 2} & =-0,413 \\
\text { R Square } & =0,171(17,10 \%) \\
\rho_{\mathrm{x} 2 € 1} & =0,829(82,90 \%) \\
\mathrm{t}_{\text {hitung }} & =-1,699\left(\mathrm{t}_{\text {tabel }}=2,160\right)
\end{array}
$$

Hal ini berarti pemberian kredit berpengaruh tidak signifikan terhadap loan to deposit ratio (LDR) dengan pengaruh yang rendah yaitu $17,10 \%$. Hal ini diduga karena faktor lain memiliki pengaruh yang lebih besar terhadap LDR yaitu $82,90 \%$, dimana faktor lain tersebut merupakan faktor dari dana masyarakat dan modal sendiri yang digunakan.

b. Pengaruh Pemberian Kredit secara Parsial terhadap Pendapatan Bunga

Bank pada PT Bank Perkreditan Rakyat Lengayang Pesisir Selatan

Hasil proses pengolahan data menunjukkan bahwa :

$$
\begin{array}{ll}
\rho_{\mathrm{x} 1 \mathrm{y}} & =0,630 \\
\text { R Square } & =0,397(39,70 \%) \\
\rho_{\mathrm{y} \in 2} & =0,603(60,30 \%) \\
t_{\text {hitung }} & =3,437\left(\mathrm{t}_{\text {tabel }}=2,160\right)
\end{array}
$$

Hal ini berarti pemberian kredit secara parsial berpengaruh signifikan terhadap pendapatan bunga bank, dimana pengaruhnya adalah sebesar 39,70\%. Hal ini sesuai dengan teori bahwa kredit yang diberikan kepada masyarakat akan mempengaruhi besarnya laba yang nantinya akan diterima bank karena salah satu 
penghasilan bank berasal dari hasil operasional bunga pemberian kredit. Adapun faktor lain yang memiliki pengaruh sebesar $60,30 \%$ terhadap pendapatan bunga bank antara lain adanya komponen-komponen dalam penentuan bunga, terutama dalam bunga kredit dan perputaran yang terjadi pada pemberian kredit tersebut.

c. Pengaruh Loan to Deposit Ratio (LDR) secara Parsial terhadap Pendapatan Bunga Bank pada PT Bank Perkreditan Rakyat Lengayang Pesisir Selatan

Hasil proses pengolahan data menunjukkan bahwa :

$$
\begin{array}{ll}
\rho_{\mathrm{x} 2 \mathrm{y}} & =-0,295 \\
\text { R Square } & =0,087(8,70 \%) \\
\rho_{\mathrm{y} \in 2} & =0,913(91,30 \%) \\
t_{\text {hitung }} & =-1,606\left(\mathrm{t}_{\text {tabel }}=2,160\right)
\end{array}
$$

Hal ini berarti loan to deposit ratio (LDR) secara parsial berpengaruh tidak signifikan terhadap pendapatan bunga bank dengan pengaruh yang lebih rendah yaitu $8,70 \%$ dibandingkan faktor lain memiliki pengaruh yang lebih besar yaitu 91,30\%. Hal ini diduga karena jumlah kredit yang diberikan selalu lebih rendah apabila dibandingkan dengan dana yang digunakan dalam perhitungan LDR, dimana jumlah kredit yang dipergunakan dalam perhitungan ini juga bukan kredit bersih melainkan kredit sebelum dikurangi penyisihan piutang aktiva produktif. Selain itu, ketidaksignifikanan tersebut dapat terjadi karena LDR merupakan rasio yang menunjukkan tingkat likuiditas dan dapat menunjukkan tingkat produktifitas pengelolaan dana, dimana semakin tinggi tingkat LDR maka semakin produktif pula aktiva yang dikelola.

d. Pengaruh Pemberian Kredit dan Loan to Deposit Ratio (LDR) secara Simultan terhadap Pendapatan Bunga Bank pada PT Bank Perkreditan Rakyat Lengayang Pesisir Selatan

Hasil proses pengolahan data menunjukkan bahwa :

$$
\begin{array}{ll}
\text { R Square } & =0,638(63,80 \%) \\
\rho_{\mathrm{y} \in 2} & =0,362(36,20 \%) \\
\mathrm{F}_{\text {hitung }} & =11,432\left(\mathrm{~F}_{\text {tabel }}=3,80\right)
\end{array}
$$

Hal ini berarti pemberian kredit dan loan to deposit ratio (LDR) secara simultan berpengaruh signifikan terhadap pendapatan bunga bank, dimana pengaruhnya adalah sebesar $63,80 \%$. Hal ini diduga karena jumlah kredit yang diberikan dan LDR secara bersama-sama memiliki pengaruh yang lebih besar dibandingkan dengan faktor lain.

\section{PENUTUP}

Kesimpulan

Berdasarkan hasil pembahasan dimana pembahasan-pembahasan tersebut selaras dengan permasalahan yang diteliti, maka dapat dibuat simpulan sebagai berikut :

1. Kondisi Pemberian Kredit, Loan to Deposit Ratio (LDR) dan Pendapatan Bunga Bank pada PT BPR Lengayang Pesisir Selatan pada periode 2006 sampai dengan 2009 sesuai dengan laporan keuangan yang disajikan secara triwulanan menunjukan bahwa: 
a. Kondisi jumlah kredit yang diberikan pada periode tersebut relatif naik setiap triwulannya. Walaupun terjadi penurunan pada beberapa triwulan namun penurunan tersebut tidak terlalu besar. Kondisi ini diduga karena permintaan terhadap kredit yang berfluktuasi.

b. Loan to deposit ratio (LDR) pada periode tersebut pada umumnya berada di bawah batas aman yang disepakati sebagian praktisi perbankan, hal ini dikarenakan dalam perhitungan LDR tidak hanya dana masyarakat saja yang digunakan sebagai pembanding akan tetapi juga modal.

c. Kondisi pendapatan bunga pada periode tersebut menunjukan terjadinya kenaikan dan penurunan yang tidak stabil dan cukup besar. Hal ini diduga karena terjadinya faktor-faktor seperti terjadinya kredit bermasalah atau persaingan.

2. Pengaruh Pemberian Kredit terhadap Loan to Deposit Ratio (LDR) pada PT BPR Lengayang Pesisir Selatan, berdasarkan hasil analisis diperoleh hasil bahwa pemberian kredit berpengaruh tidak signifikan terhadap loan to deposit ratio (LDR) dengan pengaruh yang rendah. Hal ini diduga karena faktor lain memiliki pengaruh yang lebih besar terhadap LDR, dimana faktor lain tersebut merupakan faktor dari dana masyarakat dan modal sendiri yang digunakan.

3. Pengaruh Pemberian Kredit secara parsial terhadap Pendapatan Bunga Bank pada PT BPR Lengayang Pesisir Selatan, berdasarkan hasil analisis diperoleh hasil bahwa pemberian kredit secara parsial berpengaruh signifikan terhadap pendapatan bunga bank. Hal ini sesuai dengan teori bahwa kredit yang diberikan kepada masyarakat akan mempengaruhi besarnya laba yang nantinya akan diterima bank karena salah satu penghasilan bank berasal dari hasil operasional bunga pemberian kredit. Adapun faktor lain yang memiliki pengaruh terhadap pendapatan bunga bank antara lain adanya komponenkomponen dalam penentuan bunga, terutama dalam bunga kredit dan perputaran yang terjadi pada pemberian kredit tersebut.

4. Pengaruh Loan to Deposit Ratio (LDR) secara parsial terhadap Pendapatan Bunga Bank pada PT BPR Lengayang Pesisir Selatan, berdasarkan hasil analisis diperoleh hasil bahwa loan to deposit ratio (LDR) secara parsial berpengaruh tidak signifikan terhadap pendapatan bunga bank dengan pengaruh yang lebih rendah dibandingkan faktor lain memiliki pengaruh yang lebih besar. Hal ini diduga karena jumlah kredit yang diberikan selalu lebih rendah apabila dibandingkan dengan dana yang digunakan dalam perhitungan LDR, dimana jumlah kredit yang dipergunakan dalam perhitungan ini juga bukan kredit bersih melainkan kredit sebelum dikurangi penyisihan piutang aktiva produktif. Selain itu, ketidaksignifikanan tersebut dapat terjadi karena LDR merupakan rasio yang menunjukkan tingkat likuiditas dan dapat menunjukkan tingkat produktifitas pengelolaan dana, dimana semakin tinggi tingkat LDR, maka semakin produktif pula aktiva yang dikelola.

5. Pengaruh Pemberian Kredit dan Loan to Deposit Ratio (LDR) secara simultan terhadap Pendapatan Bunga Bank pada PT BPR Lengayang Pesisir Selatan, berdasarkan hasil analisis diperoleh hasil bahwa pemberian kredit dan loan to deposit ratio (LDR) secara simultan berpengaruh signifikan terhadap pendapatan bunga bank. Hal ini diduga karena jumlah kredit yang diberikan 
dan LDR secara bersama-sama memiliki pengaruh yang lebih besar dibandingkan dengan faktor lain.

\section{Saran}

1. Bagi pihak bank

Berdasarkan hasil analisis penulis, pemberian kredit memiliki jumlah yang selalu lebih rendah apabila dibandingkan dengan dana masyarakat dan modal sendiri yang digunakan. Kondisi tersebut, apabila konsep perhitungan LDR yang digunakan bank sesuai dengan konsep yang digunakan penulis, maka disarankan bagi pihak bank untuk meningkatkan lagi jumlah kredit yang diberikan. Saran ini diajukan sebagai upaya untuk menghindari terjadinya dana yang tidak produktif. Untuk dapat meningkatkan jumlah kredit yang diberikan salah satu cara yang dapat dilakukan adalah dengan memberikan kemudahan dalam penetapan syarat-syarat pengajuan kredit. Selain itu, apabila jumlah kredit yang diberikan lebih ditingkatkan, maka bank akan lebih banyak memperoleh peluang untuk menghasilkan pendapatan dalam bentuk bunga. Saran ini tentunya harus disertai dengan pelaksanaan manajemen bank yang lebih baik terutama dalam manajemen kredit.

2. Bagi penelitian selanjutnya

Dengan melihat pada hasil penelitian di atas, peneliti menyarankan kepada peneliti selanjutnya untuk mencoba menambah jumlah periode variabel yang diteliti, menambah atau mengurangi variabel $\mathrm{X}$ yang diteliti dan pada perhitungan LDR menggunakan konsep yang lain, sehingga hasil dari penelitian tersebut dapat diperbandingkan apakah diperoleh hasil yang sama atau berbeda.

\section{DAFTAR PUSTAKA}

Amelia, L., \& Marlius, D. (2018). Pengendalian Kredit Dalam Upaya Menciptakan Bank Yang Sehat Pada PT. Bank Pembangunan Daerah Sumatera Barat Cabang Utama Padang. https://doi.org/10.31227/osf.io/kpc64

Alanshari, F., \& Marlius, D. (2018). Prosedur Pemberian Kredit KPR Pada PT. Bank Tabungan Negara (Persero) TBK Cabang Pembantu Bukittinggi. https://doi.org/10.31227/osf.io/rsfhc

Arief Billah. Bank Indonesia, laporan Pengawasan Perbankan 2008. www.scribd.com.

Baiya, \& Fernos, J. (2019). Analisis Faktor-Faktor Penyebab Kredit Macet Pada Bank Nagari Cabang Siteba. https://doi.org/10.31227/osf.io/4xuks

Darmawanto, \& Fernos, J. (2019). Prosedur Pemberian Kredit Pada Bank Nagari Cabang Sijunjung. https://doi.org/10.31227/osf.io/psqfy 
Dahlan Siamat. 2005. Manajemen Lembaga Keuangan, Kebijakan Moneter dan Perbankan Edisi Kelima. Jakarta : Lembaga Penerbit Fakultas Ekonomi Universitas Indonesia

Devina Ruslan. 2009. Pengaruh Penyaluran Kredit Terhadap Profitabilitas Koperasi. Universitas Siliwangi Pesisir Selatan

Eeng Ahman. 2004. Ekonomi Untuk Smu Kelas II. Bandung : Grafindo Media Pratama

Erik Bayu Wiseda. 2008. Pengaruh Loan To Deposite Ratio (LDR) Terhadap Pendapatan Bunga Bersih Bank. Universitas Siliwangi Pesisir Selatan

Erlina Sri Aprianti. 2009. Pengaruh Dana Pihak Ketiga Dan Penyaluran Kredit Terhadap Laba Operasional. Universitas Siliwangi Pesisir Selatan

Firmansyah, A., \& Fernos, J. (2019). Analisis Kredit Bermasalah Dilihat Dari Standar Non Performing Loan (NPL) Pada PT. Bank Perkreditan Rakyat (BPR) Prima Mulia Anugrah Cabang Padang. https://doi.org/10.31227/osf.io/gcj94

Ikatan Akuntan Indonesia. 2007. Standar Akuntansi Keuangan. Jakarta : Salemba Empat

Kasmir .2008. Bank Dan Lembaga Keuangan Lainnya. Jakarta : PT Raja Grafindo Persada

Lukman Dendawijaya. 2009. Manajemen Perbankan, edisi kedua. Jakarta : Ghalia Indonesia

Malayu S.P. Hasibuan. 2005. Dasar-Dasar Perbankan. Jakarta : PT. Bumi Aksara

Mohamad Nazir. 2003. Metode Penelitian. Jakarta : Ghalia Indonesia

Nirwana Sitepu. 1994. Path Analysis. Jakarta : Ghalia Indonesia.

Orlando, A., \& Susanto, R. (2019). Mekanisme Pencairan Kredit Usaha Rakyat Pada PT. Bank Rakyat Indonesia Unit Lubuk Buaya. https://doi.org/10.31219/osf.io/zuv2y

Pratama, D., \& Fernos, J. (2019). Prosedur Pelaksanaan Kredit Usaha Rakyat (KUR) Pada PT. Bank Nagari Cabang Padang. https://doi.org/10.31227/osf.io/ag68j

Rachmat Firdaus dan Maya Ariyanti. 2004. Manajemen Perkreditan Bank Umum. Bandung : Alfabeta 
Sigit Triandaru dan Totok Budisantoso. 2006. Bank Dan Lembaga Keuangan Lain, Edisi 2. Jakarta : Salemba Empat

Sugiyono. 2008. Metode Penelitian Kuantitatif, Kualitatif dan R\&D. Bandung : Alfabeta

Thomas Suyatno, Djuhaepah T. Marala, Azhar Abdullah, Johan Thomas Aponno, Tinon Yunianti Ananda, dan Chalik. 1999. Kelembagaan Perbankan. Jakarta : PT Gramedia Pustaka Utama

Widayati, R. (2019). Aktivitas Pemberian Kredit Komersil Pada Bank Nagari Cabang Sijunjung. https://doi.org/10.17605/OSF.IO/QTVZ9

Widayati, R. (2019). Pelaksanaan Kredit Pada Bank Perkreditan Rakyat LPN Pasar Baru Durian Sawahlunto. https://doi.org/10.17605/OSF.IO/5HPAB

Widayati, R. (2019). Aktivitas Pemberian Kredit Usaha Pada PT. Bank Perkreditan Rakyat Batang Kapas. https://doi.org/10.17605/OSF.IO/EDPN4

Yuyun Nurul Aini. 2006. Analisis Pengaruh Capital Adequacy Ratio, Loan To Deposite Ratio, Return On Assets, dan Besaran Perusahaan Terhadapa Perubahan Laba Perusahaan Perpankan yang Terdaftar di Bursa Efek Jakarta (BEJ). Universitas Negeri Semarang

Yasman, R., \& Afriyeni, A. (2019). Prosedur Pemberian Kredit Pada PT. Bank Pekreditan Rakyat (BPR) Jorong Kampung Tangah (JKT) Pariaman Cabang Padang. https://doi.org/10.31219/osf.io/c5ufr 